S. K. OLIIEVSKA, O. V. KUZMINSKA, T. I. TRUNINA (Kyiv, Ukraine)

\title{
THE CHANGES IN THE BLOOD AGREGATIVE SYSTEM UNDER THE INFLUENCE OF LEAD CHLORIDE ON THE EXAMPLE OF ALBINO RATS
}

\author{
A. Bogomolets National Medical University < svetoli@i.ua>
}

Experimentally established, that lead chloride affects all link systems of hemostasis, causing latent passing of disseminated intravascular coagulation. Observed significant depression of enzymatic, fibrinolytic activity of the cortical substance of the kidney, which indicatesthe prevalence of coagulopathic and nephrotoxic effects of small doses of plumbum chloride.

Key words: lead; hemostasis; fibrinolisis.

Introduction. Among the toxic factors of the external environment duringthe last time, great value has heavy metals salts, including lead which mainly gets into an organism with food and drinking water $[2,5,7]$.

Chronic effect of lead on human and on the animal organismoccurs practically in all the links of hemostasis with the development of disseminated intravascular coagulationIt is established, that lead intoxication leads to thrombocytopenia and reduction of thrombocyte, appearance in peripheral blood flowmacroplatelets, aggravated production of prostaglandin $\mathrm{E}_{2}$ by macrophages. Systemic disorders of hemodynamics which arise as a result of the influence of lead on the kallikrein-kinin system, renin-angiotensin andsympathetic-adrenal system promote activation platelet-vascular and coagulation hemostasis [1, 4, 9, 10].

However, there is no clear scientific evidence regarding the influence of lead on tissue fibrinolysis, which causes lysis outside the vascular depositions of fibrin, especially in the development of the syndrome of disseminated intravascular coagulation [6].

Therefore, despite the fact that in the literature there are many works devoted to the disclosure mechanisms of negative influence of lead on the human body $[2,5,8]$, there a question of the effect of small doses of lead on the system of regulating the aggregate state of blood and tissue fibrinolysis.

The purpose of our investigation is to study the changes in the processes of blood coagulation against blood clotting, plasma and tissue fibrinolysis under the reaction of sub-chronic effects of small doses of lead chloride on the body of albino rats.

Materials and methods. Experiments were performed on 24 males (14-test, 10control) albino rats weighing from 0.15 to $0.18 \mathrm{~kg}$. Within 2 weeks, the test group rats received wheat grain, and instead of water, the experimental group of rats used $0.0001 \%$ solution of lead chloride with an estimated average daily dose of metal from 23.3 to $36.7 \mathrm{ng} / \mathrm{kg}$ body weight. Control rats were on a similar diet with a free access to water supply. On the 14-th day of the experiment, 2 hours after the water load (5\% body weight, intragastric) and under a light etheric anesthetic, blood was collected from the abdominal aorta in the experimental and control group of rats. Immediately after euthanasia of organs (kidneys, heart, liver, and lungs) were frozen in liquid nitrogen for further biochemical studies. To study the regulation of the aggregate state of the blood as a stabilizer $3.8 \%$ solution of sodium citrate (1:9) was used. The state of platelet-vascular hemostasis was estimated by the percentage of adhesive platelets [3], as well as the index of platelet aggregation [10]. General coagulative blood potentials, fibrinolytic activity of plasma, the level of fibrinogen in the blood plasma, activity of antithrombin III, the concentration of soluble fibrin-monomer complexes in the blood and products of fibrin degradation in urine was determined by using reagents from «Simko Ltd» (Ukraine). Statistical processing of received data was conducted by using computer programs "Excel" and "Statgraphics" (USA). 
Results and discussion. The use of small doses of lead chloride in animals in an experiment leads to changes in the system of secondary hemostasis (Table 1).

Table 1. Influence of chloride lead on the general potential of hemocoagulation in white rats $(x \pm \delta)$

\begin{tabular}{lccc}
\hline \multicolumn{1}{c|}{ Indexes } & $\begin{array}{c}\text { Control } \\
(n=10)\end{array}$ & $\begin{array}{c}\text { Introduction of plumbum chloride } \\
\text { (number of white rats } n=14)\end{array}$ & $\mathrm{P}$ \\
\hline \hline Plasma recalcification time, sec & $53,86 \pm 1,81$ & $69,29 \pm 3.68$ & $<0.01$ \\
Prothrombin time, sec & $13,10 \pm 1,39$ & $20,00 \pm 1,24$ & $<0.01$ \\
Thrombin time, sec & $5,05 \pm 0,22$ & $15,14 \pm 0,98$ & $<0.001$ \\
Concentration of fibrinogen in blood & $3,44 \pm 0,24$ & $3,34 \pm 0,08$ & $<0.001$ \\
plasma, g/l & & & $<0.001$ \\
Antithrombin activity III, \% & $115,60 \pm 0,95$ & $87,86 \pm 1,92$ & $<0.05$ \\
$\begin{array}{l}\text { Activated partial thromboplastin } \\
\text { time, sec }\end{array}$ & $26,19 \pm 0,44$ & $29,64 \pm 1,27$ & \\
\hline
\end{tabular}

$\mathrm{P}$ - degree probability of difference indicators in comparison with control; $n$ - number of observations (number of white rats).

Thereby, time for the recalcification of the plasma continued at $57.98 \%$. It also increased prothrombin time by $52.67 \%$, thrombin time by $199.8 \%$, activated partial thromboplastin time by $1.54 \%$. All of this indicates a decrease in the overall hematopoietic potential. The level of fibrinogen in the blood plasma practically did not change, and the activity of anti-thrombin III decreased by 1.3 times. The last fact points the beginning of debilitation functional reserves of the anticonvulsant system in blood.

Discovered increase in the index of spontaneous aggregation of platelet in 1.3 times $(\mathrm{P}<0.01 ; n=22)$ and an increase in the number of adhesive thrombocytes by $91.52 \%$ $(\mathrm{P}<0.001 ; n=24)$, tells us about the activation of the platelet component of the initial hemostasis (Fig. 1).

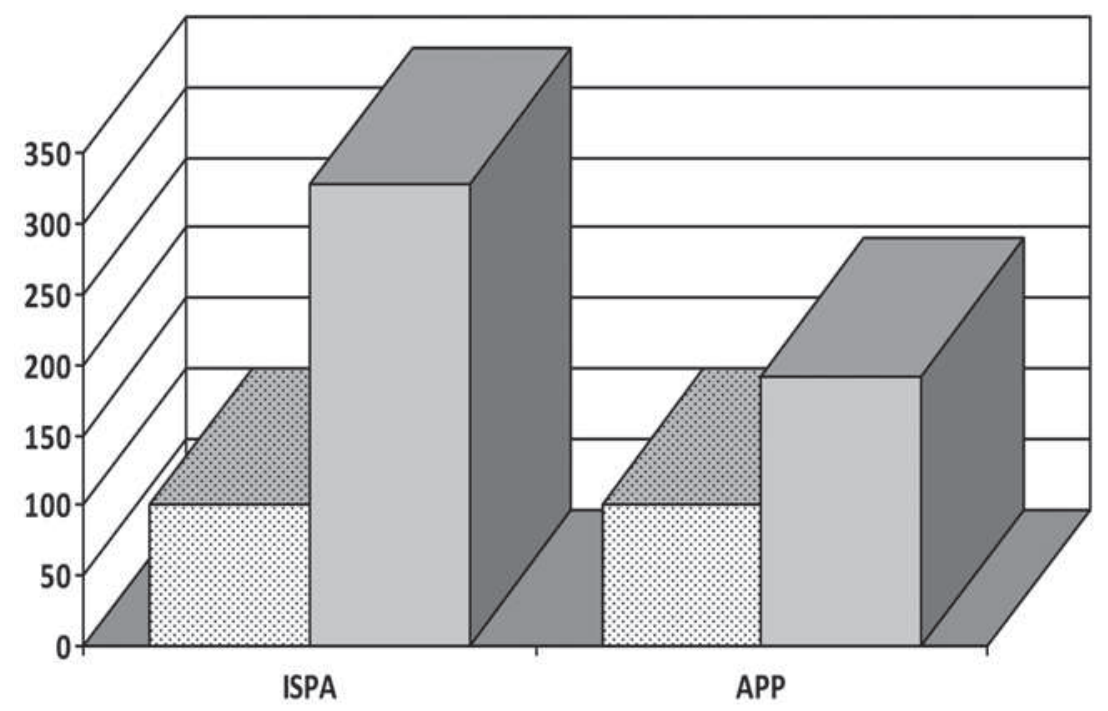

Fig. 1. Effect of lead chloride on adhesive-aggregation capacity of platelets (in \% of control):

$3-\mathrm{PbCl}_{2} ; \square$ - control; ISPA - index of spontaneous platelet aggregation; APP - adhesive platelets percentage

Observed decreased activity of the Lucky-Laurent factor $(\mathrm{P}<0.001 ; n=24)$ on the background of increasing concentration of soluble fibrin-monomer complexes in blood plasma with the appearance of fibrin/fibrinogen degradation products in urine (Fig. 2), indicating intravascular haemocoagulation. 


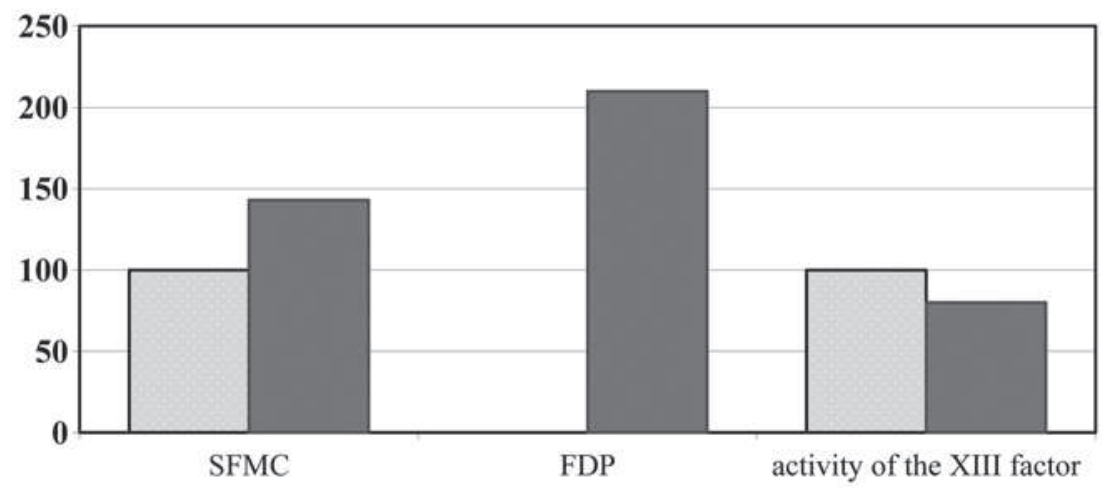

Fig. 2. Influence of chloride lead on the criterion of intravascular hemocoagulation (in \% of control): $\square-\mathrm{PbCl}_{2} ; \square$ - control; FDP - products of fibrin / fibrinogen degradation in urine; SFMC soluble fibrin-monomer complexes

Changes in the fibrinolytic blood system under the influence of chloride lead were characterized by an increase in total $(\mathrm{P}<0.001 ; n=24)$, non-enzymatic $(\mathrm{P}<0.001$; $n=24)$ and enzymatic ( $\mathrm{P}<0.001 ; n=24)$ fibrinolysis (Fig. 3 ).

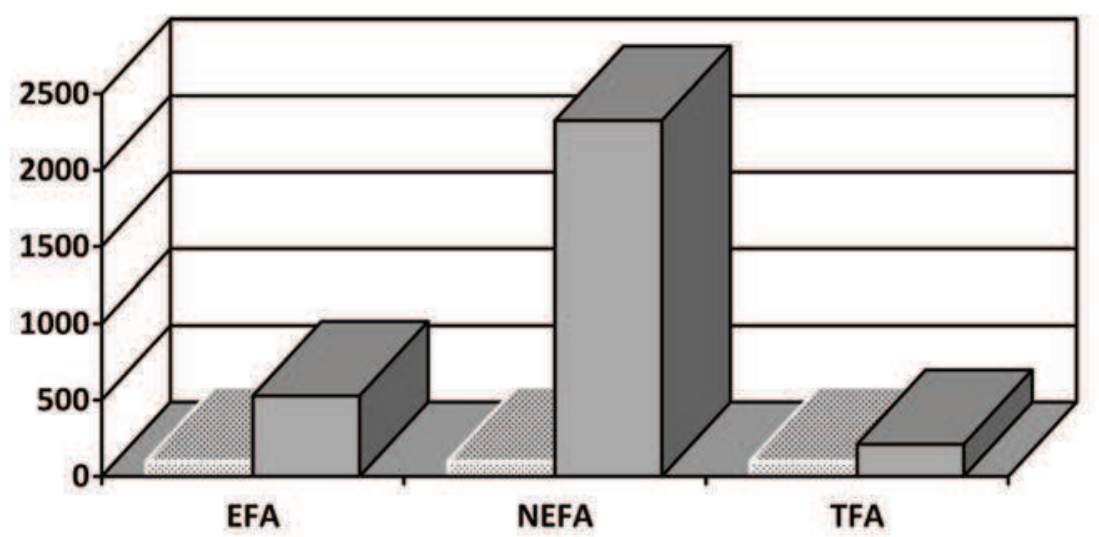

Fig. 3. Influence of the chloride lead on fibrinolytic activity of plasma (in\% of control):

- $\mathrm{PbCl}_{2}$; $\square$ - control; TFA - total fibrinolytic activity; NEFA - non-enzymatic fibrinolytic activity; EFA - enzymatic fibrinolytic activity

The effect of lead chloride on tissue fibrinolytic activity of the internal organs of rats (kidneys, adrenal glands, heart, liver, lungs) was also investigated. Thus, the biochemical study of the effect of lead chloride on the tissue fibrinolytic activity of these organs is given in Table 2.

Table 2. Influence of chloride lead on tissue fibrinolytic activity of the main internal organs of white rats $(x \pm \delta)$

\begin{tabular}{l|c|c|c}
\hline $\begin{array}{c}\text { Fibrinolytic activity (FA) of the main internal } \\
\text { organs }\end{array}$ & $\begin{array}{c}\text { Control } \\
(n=10)\end{array}$ & $\begin{array}{c}\text { Introduction of chloride lead } \\
(\text { number of white rats, } n=14)\end{array}$ & $\mathrm{P}$ \\
\hline \hline FA of cortical kidney material, E440/ml/h & & & \\
$\quad$ total & $22,70 \pm 2,78$ & $7,57 \pm 0,20$ & $<0.001$ \\
$\quad$ non-enzymatic & $1,64 \pm 0,27$ & $4,05 \pm 0,17$ & $<0.001$ \\
$\quad$ enzymatic & $21,06 \pm 0,83$ & $3,52 \pm 0,14$ & $<0.01$ \\
FA of the myocardium, E440/ml/h & & \\
$\quad$ total & $9,97 \pm 1,13$ & $9,90 \pm 0,41$ & $<0.001$ \\
$\quad$ non-enzymatic & $5,90 \pm 1,15$ & $6,14 \pm 0,37$ & $<0.001$ \\
enzymatic & $4,06 \pm 1,08$ & $3,70 \pm 0,15$ & $<0.001$
\end{tabular}


Continuation table 2

\begin{tabular}{l|c|c|c}
\hline $\begin{array}{c}\text { Fibrinolytic activity (FA) of the main internal } \\
\text { organs }\end{array}$ & $\begin{array}{c}\text { Control } \\
(n=10)\end{array}$ & $\begin{array}{c}\text { Introduction of chloride lead } \\
\text { (number of white rats, } n=14)\end{array}$ & $\mathrm{P}$ \\
\hline \hline $\begin{array}{l}\text { FA of the liver, E440/ml/h } \\
\quad\end{array}$ & & \\
$\quad$ total & $6,97 \pm 1,22$ & $10,07 \pm 0,59$ & $<0.02$ \\
$\quad$ non-enzymatic & $3,37 \pm 0,55$ & $6,26 \pm 0,42$ & $<0.001$ \\
$\quad$ enzymatic & $3,60 \pm 0,89$ & $3,81 \pm 0,38$ & $<0.001$ \\
FA of the lungs, E440/ml/h & & \\
$\quad$ total & $9,34 \pm 2,02$ & $13,60 \pm 3,02$ & $<0.001$ \\
$\quad$ non-enzymatic & $5,56 \pm 2,20$ & $8,60 \pm 1,67$ & $<0.001$ \\
$\quad$ enzymatic & $3,79 \pm 1,64$ & $5,00 \pm 1,94$ & $<0.001$ \\
\hline
\end{tabular}

$\mathrm{P}$ - degree of probability of difference of indicators in comparison with control; $n$ - number of observations (number of white rats).

The most significant changes were observed from tissue fibrinolysis in the cortical kidney. The total fibrinolytic activity decreased almost 3 times, non-fermented fibrinolysis increased by $146.95 \%$ with significant (82.29 \%) suppression of enzymatic fibrinolytic activity.

Fibrinolytic activity of myocardium and lung tissues did not change. In the liver, the total tissue fibrinolysis increased by 1.4 times, mainly due to an increase in nonenzymatic fibrinolytic activity (by $85.86 \%$ ).

Consequently, reduction of tissue fibrinolysis under the influence of small doses of chloride lead was observed only in the cortical tissue of the kidneys.

Our studies have confirmed the increase of the adhesive-aggregation capacity of platelets, the decrease of fibrinase activity and an increase of concentration in fibrinmonomer soluble complexes in blood as the fibrinolytic activity of plasma was increased.

According to our observations, lead reduces the total enzymatic and non-enzymatic activity of the renal cortical tissue, indicating an overwhelming coagulopathic and nephrotoxic effect, and can play a significant role in the pathogenesis of kidney damage in lead intoxication.

Conclusions. 1. The main feature of the toxic influence of lead chloride on the system of regulating the aggregate state of blood is the activation of platelet-vascular hemostasis with the development of intravascular hemocoagulation. 2. Changes in coagulation hemostasis are secondary and due to the inhibitory effect of fibrin/fibrinogen degradation products and the final stages of fibrinogenesis. 3. Inhibition of renal tissue fibrinolysis indicates the nephrotoxicity of small doses of lead, due to its organotrophy and high cumulative capacity.

$$
\text { References }
$$

1. Апихтіна О. Л., Кочюруба А. В., Андрусишина I. М. та ін. Продукція оксиду азоту в печінці за умов впливу ацетату свинцю в експерименті // Соврем. пробл. токсикологии. - 2007. - № 2. - С. 22-26.

2. Выглежанина Т. А., Манеева О.А., Рыжковская Е. Л. Симпатическая иннервация некоторых эндокринных органов при хроническом действии ацетата свинца // Морфология. - 1998. - Т. 113, № 1. C. $82-86$.

3. Мищенко В. П., Крохмаль Н. В., Надутый К. $A$. Простой метод определения адгезивно-агрегационных свойств тромбоцитов // Физиол. журн. - 1980. - Т. 26, № 2. - С. $282-283$.
1. Apihtina O. L., Kocyuruba A. V., Andrusishina I. M. ta in. Produkciya oksidu azotu $\mathrm{v}$ pechinci zaumov vplivu acetatu svincyu $\mathrm{v}$ eksperimenti // Sovrem. probl. toksikologii. - 2007. - № 2. - S. 22-26.

2. Vyglezhanina T. A., Maneeva O.A., Ryzhkovskaya E. L. Simpaticheskaya innervaciya nekotoryh ehndokrinnyh organov pri hronicheskom dejstvii acetata svinca // Morfologiya. - 1998. - T. 113, № 1. - S. 8286.

3. Mishchenko V. P., Krohmal' N. V., Nadutyj K. A. Prostoj metod opredeleniya adgezivno-agregacionnyh svojstv trombocitov // Fiziol. zhurn. - 1980. - T. 26, № 2. - S. 282283. 
4. Першин О. І., Антоняк Г. Л. Вплив іонів свинцю на пероксидну оксидацію ліпідів та активність ферментів антиоксидантної системи в еритроцитах щурів // Експерим. та клін. фізіологія і біохімія. - 2005. № 3. - С. 19-24.

5. Черниченко I. О., Баленко Н. В., Литвиненко О. М. та ін. Комбінована дія канцерогенних та токсичних хімічних забруднень навколишнього середовища як фактор небезпеки збільшення канцерогенного ризику // Гігієна населених міст. - 2004. Вип. 44. - С. 148-154.

4. Pershin O. I., Antonyak G. L. Vpliv ioniv svincyu na peroksidnu oksidaciyu lipidiv ta aktivnist' fermentiv antioksidantnoï sistemi v eritrocitah shchuriv // Eksperim. ta klin. fiziologiya i biohimiya. - 2005. - № 3. S. 19-24.

5. Chernichenko I. O., Balenko N. V., Litvinenko O. M. ta in. Kombinovana diya kancerogennih ta toksichnih himichnih zabrudnen' navkolishn'ogo seredovishcha yak faktor nebezpeki zbil'shennya kancerogennogo riziku // Gigiena naselenih mist. - 2004. Vip. 44. - S. 148-154.

6. An H. C., SungJ. H., Lee J. et al. The association between cadmium and lead exposure and blood pressure among workers of a smelting industry: a cross-sectional study // Occup. Environ. Med. - 2017. - Vol. 29. - P. 47.

7. Ghanwat G., Patil A.J., PatilJ. et al. Biochemical effects of lead exposure on oxidative stress and antioxidant status of battery manufacturing workers of Western Maharashtra // J. of Clin. and Diagnostic Research : JCDR. - 2016. - Vol. 10, N 4. - P. BC08-BC11.

8. Jangid A. P., John P.J., Yadav D. et al. Impact of chronic lead exposure on selected biological markers // Indian. J. Clin. Biochem. - 2012. - Vol. 27, N 1. - P. 83-89. doi: 10.1007/s12291011-0163-x.

9. Chia K. S. Urinary N-acetyl- $\beta$-D-glucosaminidase (NAG) and esposure to inroganic lead // Occup. and Environ. Med. - 1995. - Vol. 52, N 4. - P. 285-287.

10. Karlova O., Grinzovskyy A., Kuzminska O., Karvatsky I. Hyperhomocysteinemia as a predictor of cardiovascular diseases in lead-exposed subjects // Georgian med. News. - 2017. - Vol. 271, N 10. - P. 86-91.

11. Taccola A., Gotti G. B., Baruffini A., Cipolli P. L. Su un metodo di determinazione quantitative dellaaggregabilitaspontanea // Rass. Med. Sper. - 1980. - Vol. 27, N 12. - P. 795-804.

\title{
ВПЛИВ ХЛОРИСТОГО СВИНЦЮ НА СИСТЕМУ РЕГУЛЯЦІЇ АГРЕГАТНОГО СТАНУ КРОВІ У БІЛИХ ЩУРІВ
}

\section{С. К. Олієвська, О. В. Кузьмінська, Т. І. Труніна (Київ)}

Встановлено, що хлористий свинець впливає на всі ланки системи гемостазу, викликаючи латентний перебіг дисемінованого внутрішньосудинного зсідання крові. При цьому спостерігається суттєве пригнічення ферментативної, фібринолітичної активності кіркової речовини нирок, що свідчить про превалюючі коагулопатичні і нефротоксичні ефекти низьких доз хлористого свинцю.

Ключові слова: свинець; гемостаз; фібриноліз.

\section{ВЛИЯНИЕ ХЛОРИСТОГО СВИНЦА НА СИСТЕМУ РЕГУЛЯЦИИ АГРЕГАТНОГО СОСТОЯНИЯ КРОВИ У БЕЛЫХ КРЫС}

\author{
С. К. Олиевская, Е. В. Кузьминская, Т. И. Трунина (Киев)
}

Установлено, что хлористый свинец влияет на все звенья системы гемостаза, вызывая латентное течение диссеминированного внутрисосудистого свёртывания крови. При этом наблюдается существенное угнетение ферментативной, фибринолитической активности коркового вещества почек, что свидетельствует о преобладающих коагулопатических и нефротоксических эффектах низких доз хлористого свинца.

Ключевые слова: свинец; гемостаз; фибринолиз. 